\title{
Geotouristic aspects of the Geopark Cabo de Gata-Níjar (Andalusia, Spain)
}

\section{Geoturystyczne aspekty Geoparku Cabo de Gata-Níjar (Andaluzja, Hiszpania)}

\author{
Marek W. Lorenc ${ }^{1 *}$, Malgorzata Janusz² \\ ${ }^{1}$ Wroctaw University of Environmental and Life Sciences, Institute of Landscape Architecture, \\ ul. Grunwaldzka 55, 50-357 Wroctaw, Poland \\ ${ }^{2}$ C/Laguna de Aguas Verdes 7, Bj C, Edificio Sicilia, Portal 2, 18008 Granada, Spain \\ ${ }^{I}$ marek.lorenc@upwr.edu.pl; ${ }^{2}$ gosjanusz@gmail.com
}

\section{* Corresponding Author}
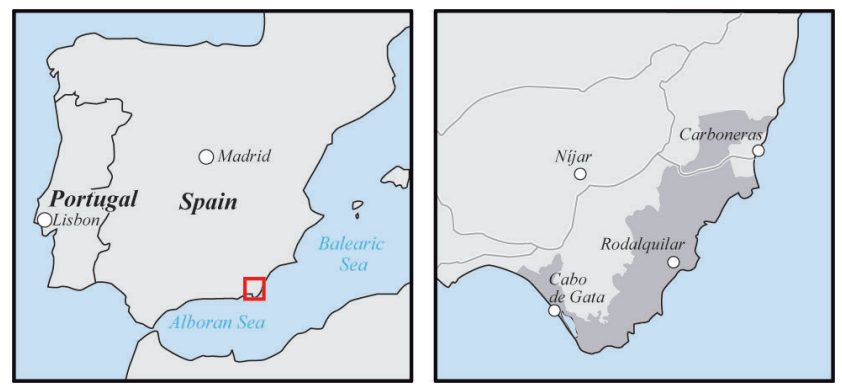

Article history:

Received: 9 January 2019

Accepted: 30 September 2019

Available online: 19 December 2019

(C) 2019 Authors. This is an open access publication, which can be used, distributed and reproduced in any medium according to the Creative Commons CC-BY 4.0 License requiring that the original work has been properly cited.

\begin{abstract}
The Cabo de Gata-Nijar Geopark is one of the most remarkable examples of the geological heritage in Spain, and it comprises the largest volcanic massif in Andalusia. It is built of andesites and dacites with such typical volcanic forms like lava flows, volcanic calderas, volcanic domes and columnar joints. The ancient beaches and reefs demonstrate the presence of climate change as well as of a subtropical sea. The tourism in this region is mainly focused on its beaches and some remains of the cultural heritage, like salt works or the Rodalquilar gold mine. This study pretends to analyze the reasons and consequences of this matter. Highlighting the good state of preservation of this area and the possibility of enjoyment of its beauty, more attention should be paid to the popularization of the local geological aspects, which would significantly increase the awareness and interest among the tourists.
\end{abstract}

Key words: geotourism, mining heritage, geopark, Cabo de Gata, Rodalquilar

Treść: Geopark Cabo de Gata-Nijar jest jednym z najbardziej niezwyklych przykladów dziedzictwa geologicznego w Hiszpanii i obejmuje największy masyw wulkaniczny w Andaluzji. Zbudowany jest z andezytów i dacytów tworzacych tak typowe formy wulkaniczne jak lawy, wulkaniczne kaldery, kopuly wulkaniczne częstokroć wykazujace oddzielność stupowa. Występowanie kopalnych plaż i raf koralowych dowodzi obecności w tym miejscu tropikalnego morza oraz zaszłych z czasem wyraźnych zmian klimatycznych. Turystyka w tym regionie koncentruje się głównie na tutejszych plażach i niektórych pozostałościach dziedzictwa kulturowego, takich jak dawne solniska lub kopalnia złota Rodalquilar. Celem artykułu była analiza przyczyn i skutków tego stanu rzeczy. Ze względu na dobry stan zachowania i piękno tego obszaru, należałoby poświęcić większa uwage popularyzacji lokalnych atrakcji geologicznych, co znacznie zwiększyłoby świadomość i zainteresowanie wśród turystów.

Stowa kluczowe: geoturystyka, dziedzictwo górnicze, geopark, Cabo de Gata, Rodalquilar

\section{Introduction}

The region of Cabo de Gata-Níjar is located in the Almeria Province, on the east coast of the Andalusia region, in southern Spain (Fig. 1). It is one of the most protected and fragile ecosystem of the whole country. It represents different types of high cultural and natural values. It should be pointed out that in particular its peculiar landscape that was created by the volcanic activity during the Neogene geological period. As a result, we can admire today an extraordinary example of the 
natural forces with their high educative values. All the characteristic forms in the landscape are perfectly conserved, and they can be clearly interpreted to explain the complex geological processes in a very demonstrative way. The Cabo de
Gata-Nijar is a unique example of the volcanic activity in the world, which has been preserved in excellent conditions. This study demonstrates the high values of that area, and considers future dilemmas as well as management strategies.

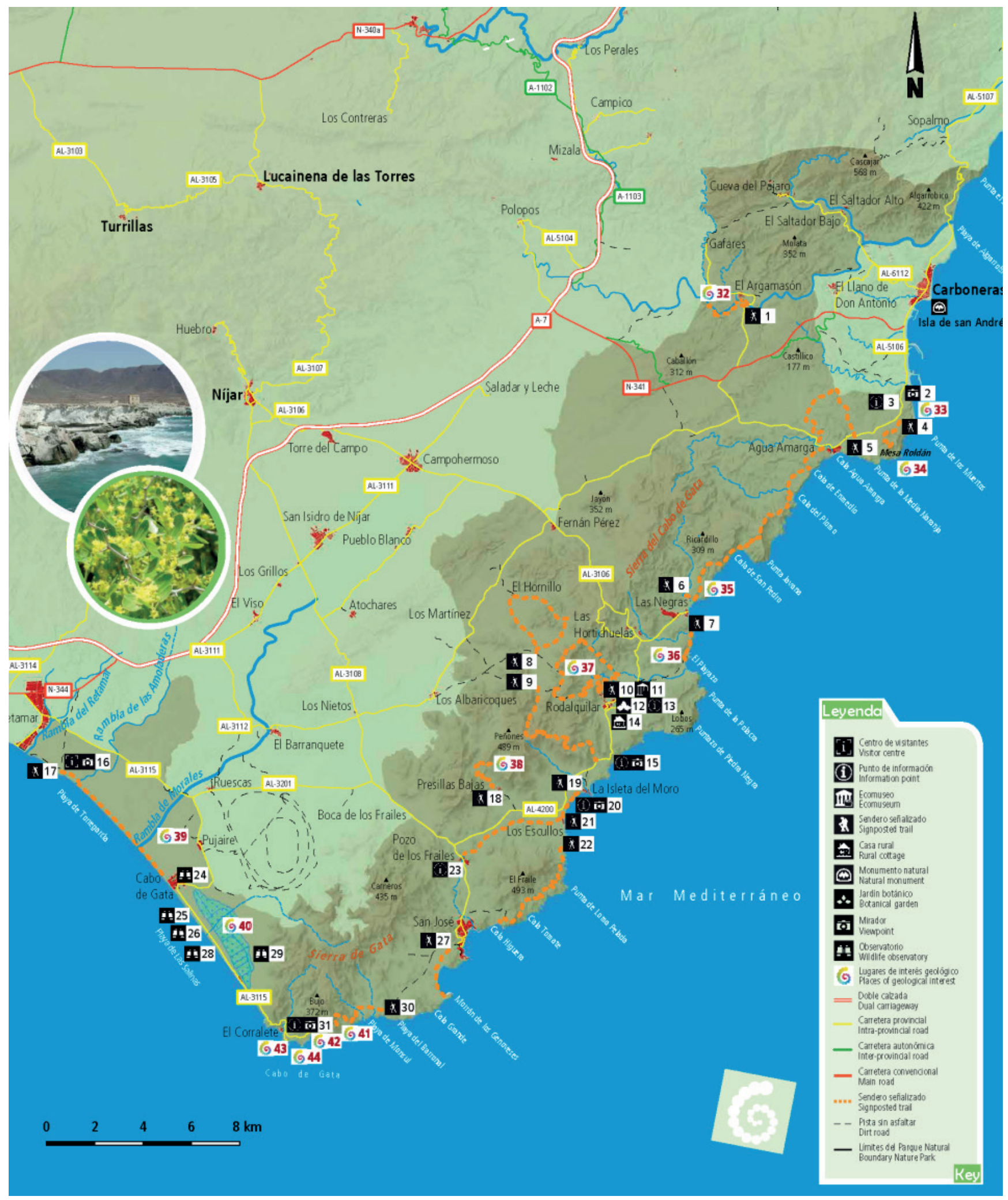

Fig. 1. Location of the Cabo de Gata-Nijar Geopark in southern Spain (www1) 


\section{Geological background}

The whole Andalusia region represents an area exposed to seismic activity, so that earthquakes are quite common. The last one of significant importance took place nearby the Lorca city (Murcia) in 2011 and measured 5.3 on the Richter scale. This phenomenon is well known and strictly registered for many years. It is provoked by the movement of the tectonic plates, and precisely in this case, the Eurasian and African ones. Sometimes, the collision between the tectonic plates can provoke earthquakes, and even volcanism. However, the seismic activity is not so strong anymore. The movements took place a long time ago just like in other parts of Europe. One of the best evidence of this activity is reflected by the Cabo de Gata Mountains that are stretched along 50 kilometres north-east of the Cabo de Gata Cape.

The volcanic activity had started here in the Middle Miocene and lasted during the Neogene from 14-15 until 7.5 million years ago. It is possible to distinguish different phases of this activity, some of which are very well preserved (Fernandez 2003, Martín Escorza \& López Ruiz, 1988). The type of volcanism in the Cabo de Gata-Níjar is identified as bimodal and represented by andesites, rhyolites, rhyodacites and dacites (Toscani et al., 1990; Rigol \& Chica-Olmo, 1998).

Due to the fact that the lava flows (Fig. 2) were acid, the eruptions were quite strong and explosive. The lava flows were also accompanied by large amounts of gases and ashes that had created ignimbrites recently and can be clearly identified in the local landscape. Some of these ignimbrites reach the shore of the sea and are intensely eroded; taking very interesting forms (Fig. 2). Sometimes, the outline of the hills is irregular. These irregularities can be perceived in the central parts of the calderas. Their formation might be provoked by two possible reasons: (1) strong eruption that blows up the upper part of the cone, or (2) the collapse of the half empty chamber after explosion. Frequently, another eruption creates a new smaller cone inside of the caldera that can collapse as a result of subsidence (Fig. 3). The eruption of the volcano located near Rodalquilar was especially spectacular. Inside of the earlier caldera with size $4 \times 8 \mathrm{~km}$, a smaller one was created with 2 kilometers of diameter. This process and its evolution were described by Rytuba et al. (1990) and Labus (2009).

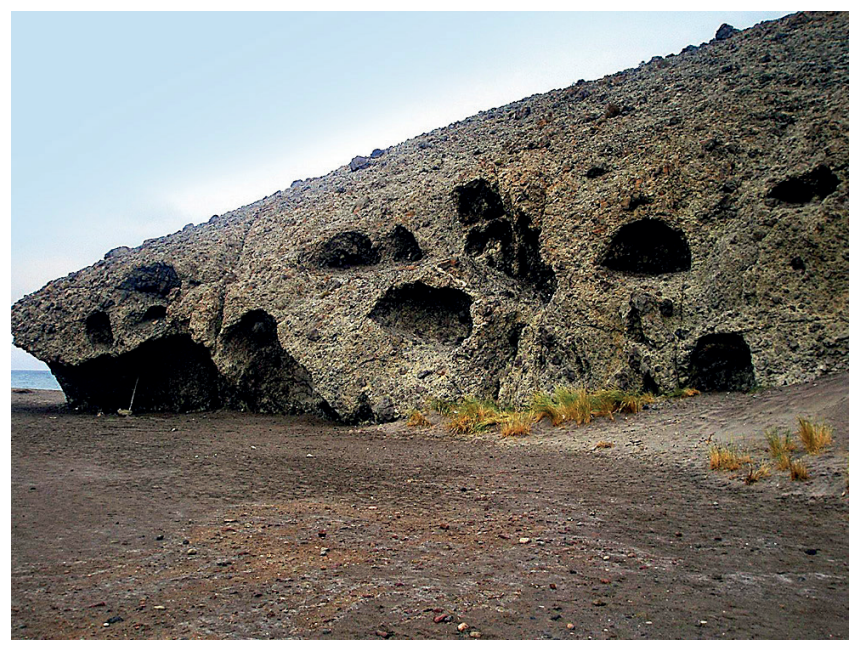

Fig. 2. Example of the ignimbrite lava flow intensively eroded by wind and see (photo M. Janusz)

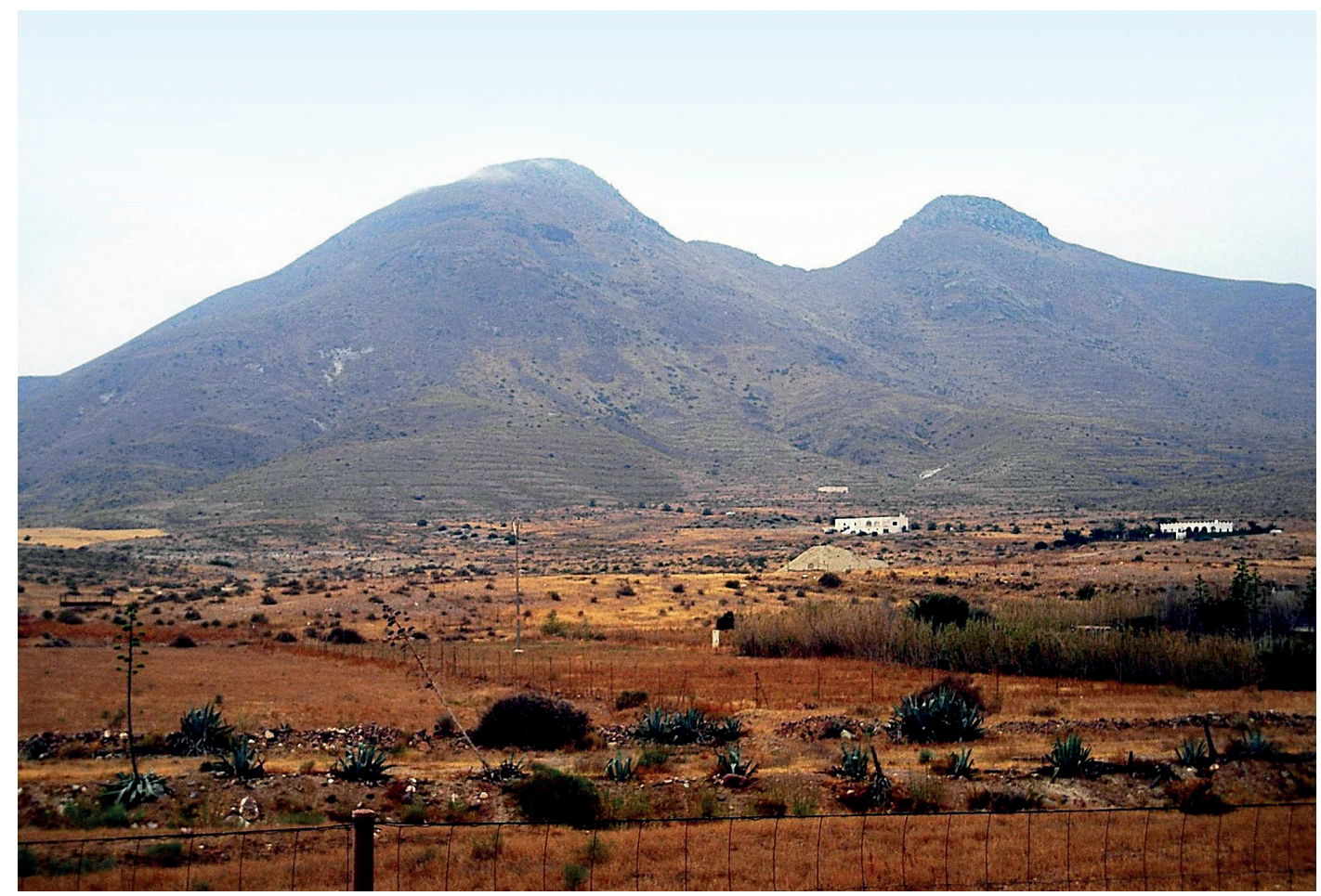

Fig. 3. Cone of the Los Frailes volcano built of ignimbrite which origin was related to the collapse of a huge Rodalquilar caldera (photo M. Janusz) 


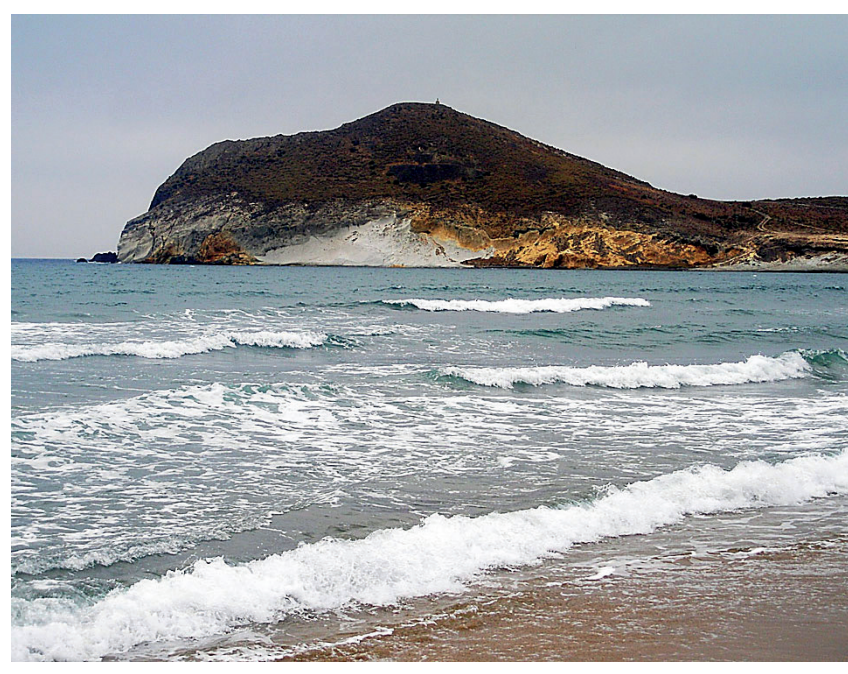

Fig. 4. The level of white ignimbrites is covered from the top by andesite lava flow (photo M. Janusz)

The final phase of the volcanic process is the migration of the hot, post-magmatic liquids in the fissures of rocks that surround the cooling magma tank. Just after the Rodalquilar caldera had collapsed, it was filled with volcanic and pyroclastic rocks (Fig. 4) and products of hydrothermal activity of the hot liquids which has started as a result of some local transformations and impregnations of different types of minerals. Numerous cracks and fissures in rhyolites, rhyodacites and ignimbrites are filled in their upper parts with clay and silica materials. Meanwhile in their lower parts, it is possible to identify ore minerals, first oxides and then sulphates.

The marine environment was transformed by climate changes and, as a result, there are different types of sediments. The sedimentary materials of the sea-bed and local depressions are formed by limestones with a great variety of organic remains, and clastic deposits like sands and gravels (Fig. 5). Nowadays, in some spots of the Cabo de Gata Mountains, it is possible to appreciate the fossil coral reefs that were located in the surroundings of the islands in the period when the thermal conditions of the climate were much higher than today (Mather et al., 2001). Nearby Agua Amarga, there is a typical example of the volcanic dome formed by one of the latest volcanic activities $(8.7$ million years ago). This dome is surrounded by 6 million years old limestones with a great variety of fossils. It is defined as a typical coral reef example and is called Mesa de Roldán (Villalobos Megía et al., 2007).

\section{Natural and cultural aspects}

Preserved results of volcanic activity have determined different aspects of this region. Generally, it is possible to distinguish two big zones with different geological and physiographical features that are Cabo de Gata Mountains and the

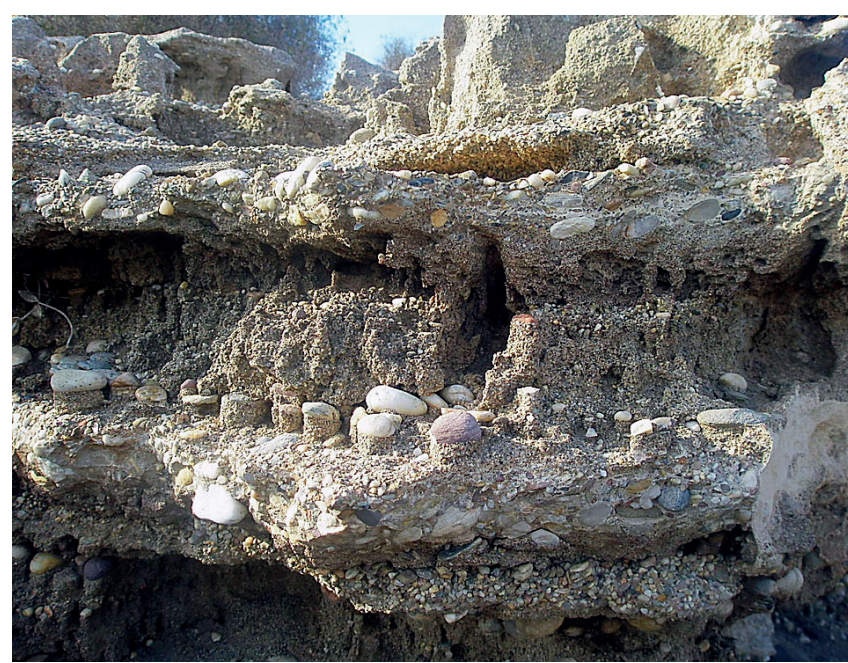

Fig. 5. The example of fractional sedimentation of clastic deposits with clear levels of pebbles, gravels and coarse sand (photo M. Janusz)

Almería Bay. One of the most important aspects to determine the zones were the complex geological processes caused by the collision of tectonic plates and lava outflow. The main part of these remains is submerged recently by the sea, but there are still some important formations that stand out at the surface or are partially submerged (Fig. 6). The Cabo de Gata Mountains reaching 493 meters above sea level are among the most important examples of volcanic activity in the Iberian Peninsula. On the contrary, the Almería Bay provides some outstanding beaches formed by fossils like the Strombus bubonius. Both ones are situated close one to another, provoking an interesting contrast and numerous examples of tiny islets, which produce an extensive marine archipelago of volcanic domes (Díaz Álvarez, 1983).

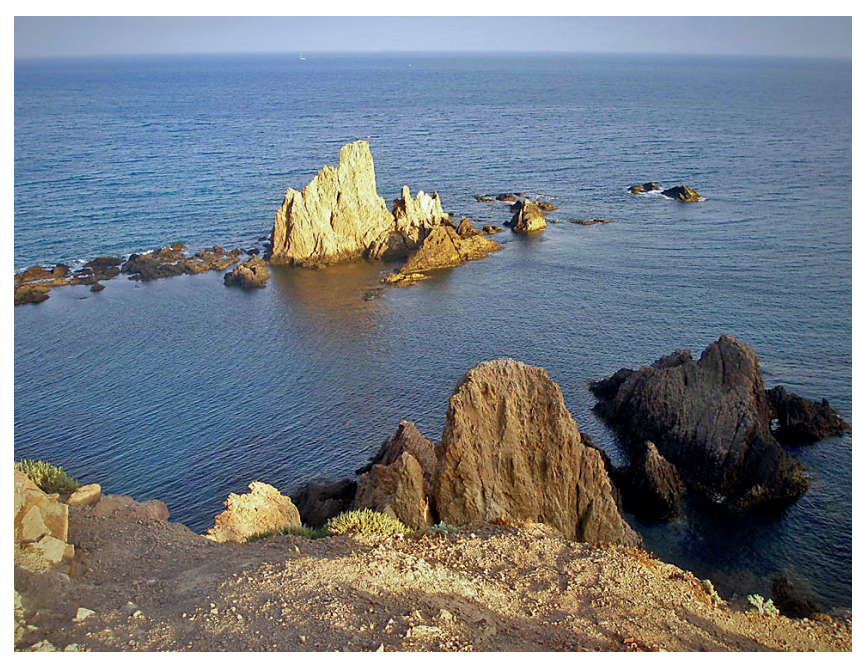

Fig. 6. Andesitic rocks partially submerged in the sea are the remains of a volcanic chimney after collapse of the caldera (photo M. Janusz) 
The entire region is subdued to extremely dry climate conditions when compared to the rest of the country. It represents a semi-desert climate with the lowest annual rate precipitation registered in the Iberian Peninsula, with $183 \mathrm{~mm}$ of average rate per year. High variations of the temperatures do not take place, and the average values oscillate from 15 to $22^{\circ} \mathrm{C}$. For that reason, the climate is defined as smooth and gentle. Nevertheless, there is some important factors that alter this serenity, in particular the wind, which can reach even 10 and $20 \mathrm{~km} / \mathrm{h}$ during most parts of the year (Muñoz Muñoz \& Ruiz García, 2002).

The extreme climate conditions, the lack of water and peculiar soils formed in the post-volcanic period have created an exceptional environment for both, flora and fauna species. At the moment, there are registered 27 natural and semi-natural habitats and almost one thousand different plant species, some of which are endemic. The most characteristic are the European fan palm (Chamaerops humilis), Iberia's largest population of jujube (Ziziphus zizyphus), a thorny shrub, populates the steppe. The scrubland is composed of olive trees (Olea europaea), mastic (Pistacia lentiscus), Kermes oaks (Quercus coccifera), esparto grass (Stipa tenacissima), thyme (Thymus) and rosemary (Rosmarinus officinalis). Around the salt region, there are colonies of saltworts, common reeds (Phragmites australis) and the glasswort (Salicornia fruticosa). In the coastal waters, there are extensive beds of sea-grass (Posidonia oceanica), which is endemic to the Mediterranean (Moreno Lampreave, 2001).

The fauna is composed by the 1100 species and most of them are birds. Once again, the salt flats provide an important habitat for both the resident birds and the thousands of migrating birds that stop on their journey between Europe and Africa, such as flamingos (Phoenicopterus roseus), grey herons (Ardea cinerea) and purple herons (Ardea purpurea), storks, cranes, waders including avocets and oystercatcher, and overwintering ducks. It is also a home for many mammals and maritime species (Moreno Lampreave, 2001).

This unusual geological landscape is one of the most outstanding examples of a fossil volcanic zone in Europe. All the natural aspects are combined, and as a result give back an exceptional landscape with a wide variety of forms, textures and colors, like different hues of red, ochre and blacks. In the light of the variety of goods and different types of resources that are present in this area, it is possible to identify some clear tracks of human activity. Some of them date back even to the Romans and Phoenicians (Mendoza et al., 2008). There are also some remains of a castle and watchtowers from the Arabic period, mostly located at the coastline.

One of the most significant cultural aspects is related to the mining activity that started to be developed in this region in the $14^{\text {th }}$ century. The most important period for the mining is related to the $19^{\text {th }}$ century, when some quartz and galena veins were discovered. Lead and silver, and less copper and tin, were mined here until the late $20^{\text {th }}$ century. From that time, a dark period started for the mining industry in the Almeria Province. Nonetheless, the discovery of gold had changed the bad luck in the region rapidly and led to swift economic and social growth. The gold was mined until the late $19^{\text {th }}$ century, with deep shaft mining and until $20^{\text {th }}$ century, with surface mining. The most important gold mine in the area was the Rodalquilar gold mine, which was closed in 1966 (Feixas, 2003; Villalobos Megía et al., 2007). Its remains occupied quite a large area and they are significant tourist attraction, although not fully prepared for tourism (Fig. 7).

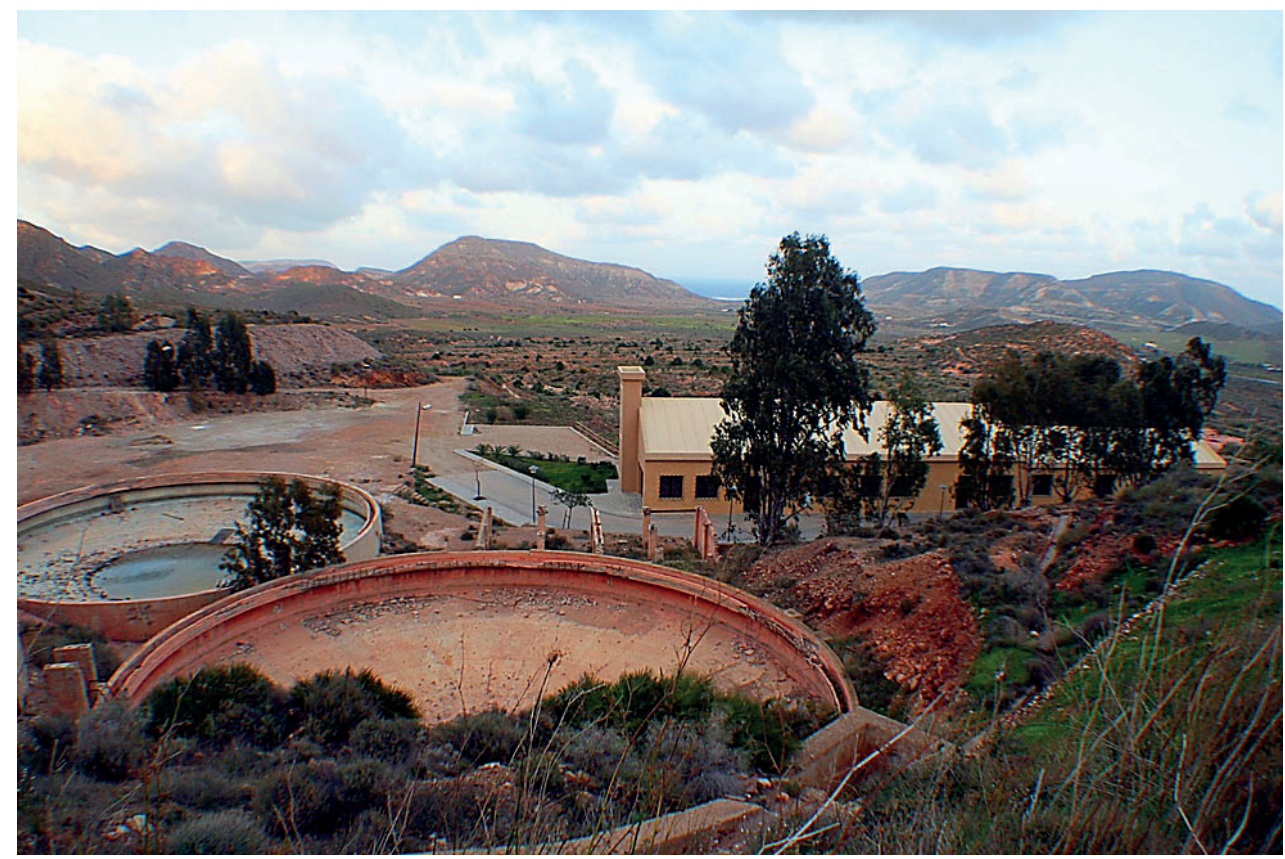

Fig. 7. The remains of the Rodalquilar gold mine: circular in shape cleaning tanks for mixture of minerals and cyanide; interpretation center to the right (photo M.W. Lorenc) 
Other important cultural activity was developed is the salt mining industry that has a long tradition initiated in the $11^{\text {th }}$ century. This type of activity has persisted until now, as it is not considered harmful for the environment.

All the high valued factors were preserved during long periods thanks to their special protection. The region Cabo the Gata-Nijar represents the most protected area in Andalusia by local, European and world regulations (Gil Albarracín, 2001). It received the status of a Geopark in 2001, but already in 1987, it was for the first time declared a Natural Park in the network of local regulations. There are lots of different legal acts and norms that protect particular elements or the whole system of this territory, for instance: Special Protection Areas (SPAs, 1989), Wetland of International Importance (RAMSAR, 1990), Reserve of the Biosphere (MAB, 1997), Specially Protected Areas of Mediterranean Importance (SPAMI, 2001), Natura 2000 (2006), European and Global Geopark (2006) and European Charter of Sustainable Tourism (ECST, 2008). In 2007, the Geopark Cabo de Gata-Níjar was declared, and its aim is to protect the valuable area and education on the basis of natural (botanical, zoological and geological) and cultural values (Mendoza Castellon, 2008).

\section{Current challenges}

The uniqueness of the Cabo de Gata Geopark was successfully preserved during long periods of time, but there is still lot of work that needs to be done. First of all, the correct balance between nature and human aspects should be assured. There are some activities that have a long tradition and already define that region. Those are mostly the mining and salt industries. Both of these activities are regulated now and though they still have strong impact on the environment, it was possible to maintain their essence. Mining, for instance, persists now as a cultural heritage and salt exploitation is limited to the special amount of production per year.

Nevertheless, there are still some activities that if not treated might represent serious problems in the short future. Agricultural exploitation within greenhouses and rapid urbanization are some of the most important and urgent issues to be resolved. What's more, the agricultural area is already strictly reduced and recently there were observed some illegal actions taken to extend it. Similar actions were taken in the urbanization sector and, as a result, some new constructions have emerged. Those kinds of problems are extremely difficult to regulate, and it may take some time to find correct solutions. So far, the local administration tries to combat these activities by ceasing them activity or imposing fines.

Although human activity is one of the most problematic, there are, however, some natural actions that may damage considerably the geopark's values. Draught, for instance is one of the most real and actual problems because of the climate conditions. Though, autumn and winter are periods when most of the precipitation takes place, those might be so intense and irregular that they might provoke inundations, which is considered as another important natural threat. The risk of fire is also high considering the climate conditions in the summer. Finally, erosion that might be provoked by both natural processes or human activities should not be ignored.

\section{Tourism and geotourism aspects}

The tourism sector represents especially an important aspect in the geopark management and needs to be analysed in a separate paragraph. The tourism explosion has started here in the 60 s of the past century and its impact was extremely strong, considering the fact that there were no special regulations for this activity at that time.

Intensive urbanization has started, and, as a result, there are still numerous constructions that produce a pronounced impact on the landscape, as they were located at the coastline. These kinds of buildings mostly correspond to hotels or residential houses that are still quite widely used as a summer residences by Spanish society. Further regulations and recent actions were taken to defeat the problem which has been considerably reduced, but still there is a long way to go. Nevertheless, actions like reduced access for cars or the delimitation of the routes for trekking are worth mentioning as outstanding actions that help to control the strong impact produced by large numbers of tourists in the region during the summer.

However, as Cabo the Gata-Níjar is one of the most famous destination for the national and world tourists, the geotourism is still not that popular. People mostly come here because of the great climate during most parts of the year, outstanding beaches and interesting landscape forms (Fig. 8). Are they really able to appreciate its geological importance and richness? Are they aware of its uniqueness?

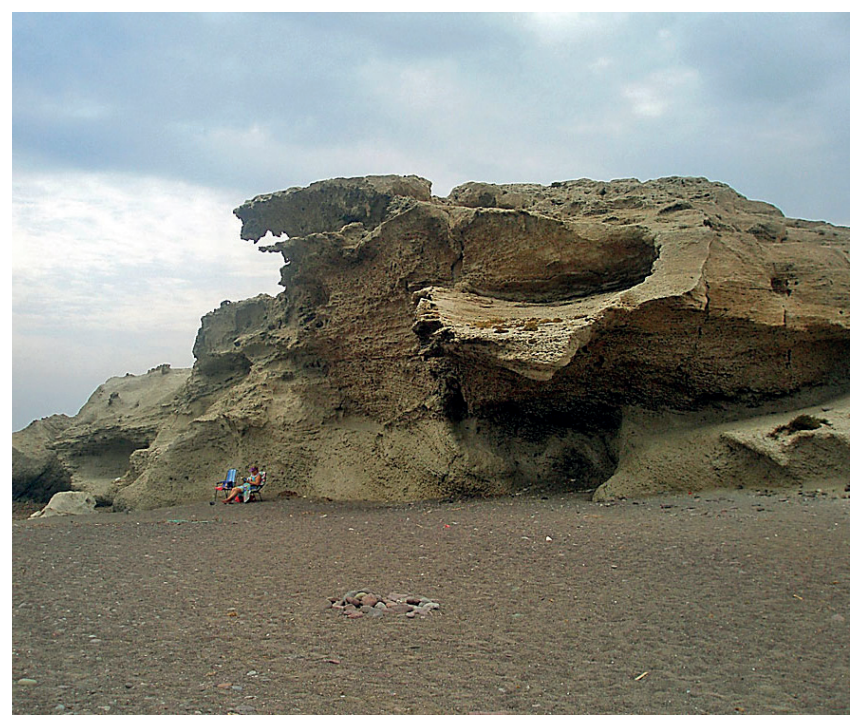

Fig. 8. Example of eolic erosion forms in the Upper Miocene shallow-marine organogenic limestones (photo M. Janusz) 
In the case of any kind of doubts, there is an educational system prepared by the local government that includes its own interpretation centre - The House of Volcano (Fig. 9). Inside, there are lots of panels and models that help to explain the complex local geological process. There are also thematic guided tours available that offer especially prepared networks of the routes of geological interest. Nonetheless, there is still so little interest from particular tourists in the outstanding geology of this region and most of the visitants are scholars and students groups. This might be a problem considering the fact that large amounts of tourists are not aware of the fragility of this place and might provoke it destructions. But then again, some important places remain solitary, so that they are mostly explored by the specialist. And this is the essence of the sustainable geotourism activity in the Cabo de Gata-Níjar Geopark.

\section{Further actions}

All future actions that will be taken in the frame of the geopark's management are centred in the sustainable development strategies. In other words, there should be an assured balance between protection and economic progress. The local government has established some important goals that should be completed in the long term plan. It contemplates the increase in the local productivity with evaluation of the natural and cultural aspects of the park. Tourism is still one of the most important factors for the local economy that should be strictly regulated. Its continuous growth might be both, beneficial and harmful. Nonetheless, the control of this activity seems to be on the right level at the moment. Some actions to will be taken to promote scientific investigation and local society involvement.

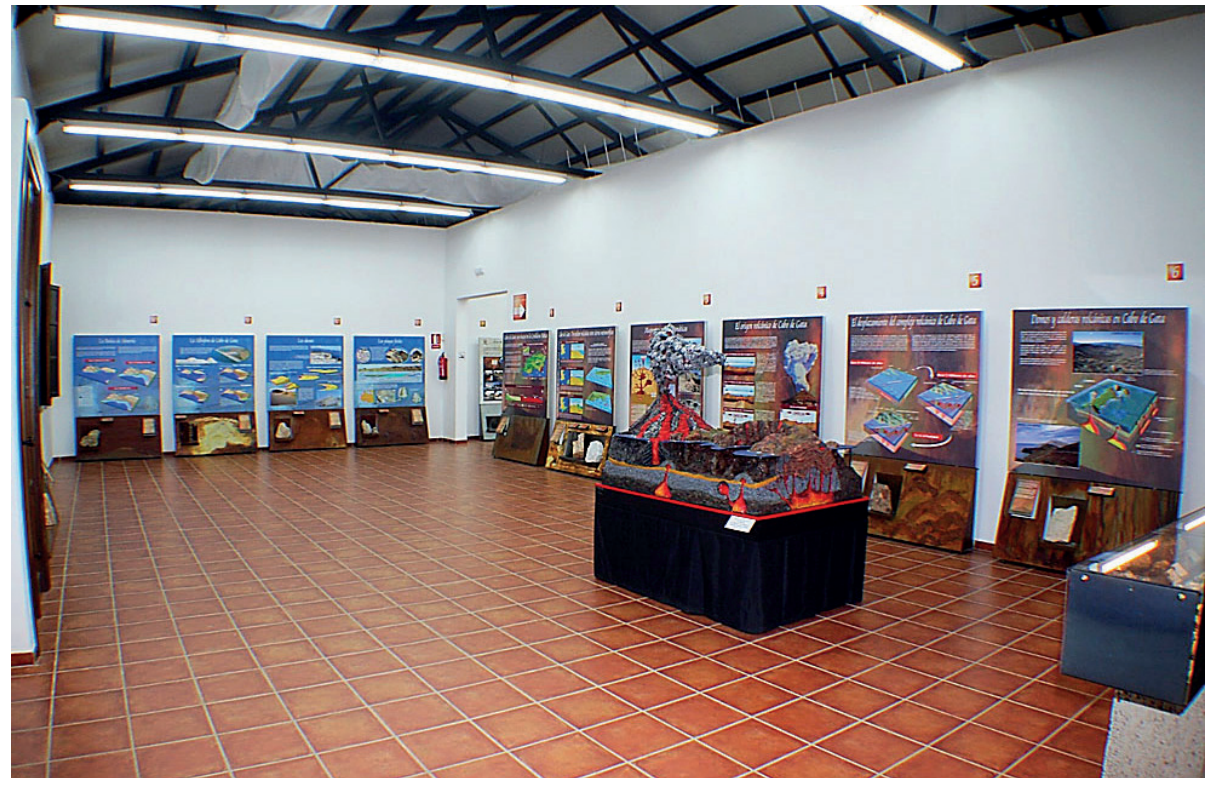

Fig. 9. The House of Volcano, interpretation center with a model of volcano and panels showing regional geology and ca. 2,000 years of mining history in the Cabo de Gata-Níjar (photo M.W. Lorenc)

\section{References}

Díaz Álvarez J.R., 1983. La Provincia de Almería: El soporte físico del espacio geográfico. Almería, t. I. Editorial Andalucía de Ediciones Anel, Granada.

Gil Albarracín A., 2001. Guía del Parque Natural Cabo de Gata-Níjar (Almería). Griselda Bonet Giraber, Granada.

Feixas C., 2003. The Rodalquilar gold. In: Villalobos Megía M. (ed.), Geology of the Arid Zone of Almeria, South East Spain. An educational field guide, State water Company for the Southern Basin S.A. (ACUSUR): 34-36.

Fernández J.M., 2003. The Cabo de Gata Volcanic Complex. In: Villalobos Megía M. (ed.), Geology of the Arid Zone of Almeria, South East Spain. An educational field guide. State water Company for the Southern Basin S.A. (ACUSUR): 29-31.
Labus M., 2009. Geologia Almerii - półpustynnej krainy Hiszpanii (Geology of Almería - semi-desert zone of Spain). Geoturystyka, 1-2 (16-17): 33-40.

Martín Escorza C. \& López Ruiz J., 1988. Un modelo geodinámico para el volcanismo neógeno del sureste ibérico. Estudios Geológicos, 44: 243-251.

Mather A.E., Martin J.M., Harvey A.M. \& Braga J.C., 2001. A Field Guide to the Neogene Sedimentary Basins of the Almeria Province, South-East Spain. Blackwell Science.

Mendoza Castellón R., 2008. Cabo de Gata: veinte años desde la declaración del Parque Natural Cabo de Gata-Nijar. Ministerio de Agricultura, Alimentación y Medio Ambiente, Secretaría General Técnica. Servicio de Publicaciones y Divulgación, Almería.

Mendoza M.R., Rivas P., Navarro Pastor J., Serna A. \& Pérez Villalba M., 2008. Geoparques andaluces, un ejemplo en la protección de la geodiversidad. Medio Ambiente, 62: 12-15. 
Moreno Lampreave D., 2001. El espectacular patrimonio natural litoral y sumergido de Cabo de Gata (España). In: Moreno D., Frias A. (eds.), Actas de las I Jornadas sobre Reservas Marinas y I Reunión de la Red Iberoamericana de Reservas Marinas (RIRM). Cabo de Gata, Almeria, 17-23 de septiembre de 2001, Secretaria General de Pesca Maritima, Madrid: 25-46.

Muñoz Muñoz J.A. \& Ruiz García A., 2002. Itinerario por Cabo de Gata y Campos de Nijar. La cultura del agua como aproximación histórica y etnográfica. Consejería de Educación y Ciencia. Consejería de Cultura. Junta de Andalucía.

Rigol J.P. \& Chica-Olmo M., 1998. Merging remote-sensing images for geological-environmental mapping: application to the Cabo de Gata-Níjar Natural Park, Spain. Environmental Geology, 34: 194-202.

Rytuba J.J, Arribas Jr. A., Cunningham C.G., McKee E.H., Podwysocki M.H., Smith J.G., Kelly W.C. \& Arribas A., 1990. Mineralized and unmineralized calderas in Spain; Part II, evolution of the Rodalquilar caldera complex and associated gold-alunite deposits. Mineralium Deposita, 25: 29-35.

Toscani L., Venturelli G., Barbieri M., Capedri S., Fernandez Soler J.M. \& Oddone M., 1990. Geochemistry and petrogenesis of two-pyroxene andesites from Sierra de Gata (SE Spain). Mineralogy and Petrology, 41: 199-213.

Villalobos Megía M., Pérez Muñoz A.B. \& Braga Alarcón J.C., 2007. Geodiversity and geological heritage of Andalusia. Geological excursions through Andalusia an educational guide. Regional Ministry of Environment, Junta de Andalusia.

www1 - http://www.juntadeandalucia.es/medioambiente/portal_web/ web/temas_ambientales/espacios_protegidos/01_renpa/canales _ figuras_proteccion/GEOPARQUES/2017_01_geoparques/cabo gata/conoce_el_geoparque_cgn/mapa_conoce_cabo_de_gata.png [accessed: 2019.09.20]. 